\title{
THE ANCIENT CITY AND THE CONTEMPORARY ANCIENT CITY
}

\author{
Gilberto da Silva Francisco ${ }^{1}$ \\ Glaydson José da Silva²
}

\begin{abstract}
“- Ah, yes! Priceless. Do you want to know something else? Having read the letters of Canon Benigno, he decided there and then to go to the backlands of Bahia in search of the mysterious city chronicled therein. He showed me the plan, described to me the likely architecture of the city, its temples and palaces built in the Etruscan style, the rites, vases, clothes, costumes -" 3
\end{abstract}

The ancient city depends on the contemporary city, and the contemporary city depends on the ancient city. Our own city's descriptions are frequently based on historical references in which the landscapes of cities such as Rome and Athens are strongly found. The lost city in the backlands of Bahia, among the references of Canon Benigno - a character of Machado de Assis' short story, Polycrates' ring - is precisely this, in its creative discourse: an unknown and mysterious city based on elements from the ancient Mediterranean city.

At the same time, ancient cities such as Rome and Athens are observed and "reconstructed" from contemporary references: for instance, as Athens becomes a "museum-city" inspired by the landscapes of museological exhibits in a work such as La Cité des Images; 4 or as Athens becomes a pivotal city, or a trans-temporal model, as proposed by George Grote; 5 or following the logic of an "exception-city" in a context in which firmly established colonial references are deconstructed, such as in De Polignac's work ${ }^{6}$ - thus laying the foundations on which Grote's "Athenocentrism" was gradually attenuated and criticized by some consistent projects that proposed a broader outlook for observing an increasingly plural ancient city. ${ }^{7}$

In other words, when we change, the ancient city also changes.

\footnotetext{
${ }^{1}$ PhD Professor at the Federal University of São Paulo, São Paulo, Brazil. E-mail: gisifran@gmail.com

2 PhD Professor at the Federal University of São Paulo, São Paulo, Brazil. E-mail: sglaydson@hotmail.com

${ }^{3}$ MACHADO DE ASSIS, J. M. de, “O anel de Polícrates". In: Papéis avulsos. 1882.

${ }^{4}$ BÉRARD, C. et al. Le Cité des images : religion et société en Grèce antique. Paris: F. Nathann, 1984.

${ }^{5}$ A History of Greece; from the Earliest Period to the Close of the Generation Contemporary with Alexander the Great (12 vols.), 1846-1856.

${ }^{6}$ La naissance de la cité grecque. Cultes, espace et société, VIIIe-VIIe siècles avant J.-C. Paris: Éd. de la Découverte, 1984.

7 See, for instance, BROCK, R.; HODKINSON, S. Alternatives to Athens. Varieties of political organization and community in ancient Greece. Oxford: Oxford University Press, 2000 e HANSEN, M. H.; NIELSEN, Th. H. An inventory of Archaic and Classical poleis. Oxford: Oxford Univesity Press, 2006.

Heródoto, Unifesp, Guarulhos, v.4, n.1 - 2019.1 p.03-04

DOI: https://doi.org/10.34024/herodoto.2019.v4.10081
} 
Another example in this sense is the current insertion of the city-logic into other more far-reaching, connected and complex landscapes that constitute a globalized perspective on the contemporary city. As the contemporary city became globalized, the same process occurred with the ancient city. Meanwhile, the reference points for concatenating the discourse on the ancient city are also essential: as in the cases of Fustel de Coulanges' religion-based city ${ }^{8}$ of Gordon Childe's city based on the modes of production amidst the context of an "Urban Revolution", ${ }^{9}$ and of Max Weber's city - where the homo politicus becomes the central element, in contrast to the homo economicus of medieval cities; ${ }^{10}$ among others.

Thus, bearing in mind the great relevance of grasping these two "cities" (the ancient and the contemporary) alongside each other - and even their mutual dependency -, it is imperative to reflect on the ancient city by considering its vestiges, but also based on its readers and on the dynamic process of the trends that place it at the center of the debates on the classical world in Antiquity and its complex linkages with the "surrounding world". It is in this setting that key concepts such as polis, politics, CityState, market, networks, landscapes, linkages and identities, among others, emerge as descriptors of how these cities were structured.

Such is the intention behind this special issue of Herodotus on "Cities and Peripheries in the Ancient World": to make a contribution by laying another modest brick in the construction of a wide and critical outlook of the ancient city based on discursive and material aspects that once were and still continue to be found in the debates that attest to their complexity. We believe that as long as debates on the ancient city continue to exist, such city continues to be alive and active as an essential reference for thinking about the city in which we live.

The contributions of this special issue, "Cities and Peripheries in the Ancient World", deal in depth with many of the issues above and include an interview with Professor Maria Beatriz Borba Florenzano (from the University of São Paulo's Museum of Archeology and Ethnology, MAE-USP), who also collaborated with this publication. We are deeply thankful to Professor Florenzano and to all who have contributed to this issue of Herodotus.

We wish you an exciting and insightful reading experience.

\footnotetext{
8 FUSTEL DE COULANGES, N.-D. A Cidade Antiga. São Paulo: Ed. das Américas, 2006.

${ }^{9}$ CHILDE, V. G. O que aconteceu na História. Rio de Janeiro: Zahar, 1977.

${ }^{10}$ WEBER, M. Economia e Sociedade. São Paulo: Ed. UnB, 2004.

Heródoto, Unifesp, Guarulhos, v.4, n.1 - 2019.1 p.03-04

DOI: https://doi.org/10.34024/herodoto.2019.v4.10081
} 